\title{
SURFACTANTS IN KLODNICA RIVER (KATOWICE, POLAND). PART I. LINEAR ALKYLBENZENE SULPHONATES (LAS)
}

\author{
OBECNOŚĆ ZWIĄZKÓW POWIERZCHNIOWO CZYNNYCH \\ W RZECE KŁODNICA (KATOWICE, POLSKA). \\ CZĘŚĆ I. LINIOWE ALKILOBENZENOSULFONIANY
}

\begin{abstract}
Surfactants are a group of compounds with specific physico-chemical properties and therefore they are used in many spheres of human activity. Surface-active substances undergo various physico-chemical transformations, what enables their migration between different elements of the environment and may lead to its pollution. Selected anionic surfactants were determined in samples of water from the Klodnica river (25 samples) and bottom sediments (25 samples). In most samples the presence of anionic analytes was confirmed. The determined concentration levels were in the range of up to $0.2105 \pm 0.0023 \mathrm{mg} / \mathrm{dm}^{3}$ or $0.207 \pm 0.010 \mu \mathrm{g} / \mathrm{kg}$ (surface water and bottom sediment samples, respectively). Comparing the concentrations of certain analytes found in liquid and solid environmental samples, it can be noticed that the surfactants containing a shorter alkyl chain in a molecule were present in higher concentrations in liquid samples (hydrophobicity increasing with the increasing length of the chain) and the other way round.
\end{abstract}

Keywords: surface-active substances, surface water, industrial area, linear alkylbenzene sulphonates

\section{Introduction}

Surfactants, also called surface-active substances, have specific physico-chemical properties, like the ability to lower surface tension and/or interfacial tension between different media as well as to dissolve in solutions of polar and/or non-polar substances [1]. Due to this fact, surface-active substances are used in different aspects of human activity, leading to their (or products of their biodegradation) systematic emission to different

\footnotetext{
${ }^{1}$ Faculty of Earth Sciences, University of Silesia, ul. Będzińska 60, 41-200 Sosnowiec, Poland, phone +48 3236894 37, email: marek.ruman@us.edu.pl

${ }^{2}$ Department of Environmental Toxicology, Faculty of Health Sciences with Subfaculty of Nursing and Institute of Maritime and Tropical Medicine, Medical University of Gdansk, ul. Dębowa 23, 80-204 Gdańsk, Poland, phone +48583491935, email: ewa.olkowska@gumed.edu.pl

${ }^{3}$ Faculty of Earth Sciences, University of Silesia, ul. Będzińska 60, 41-200 Sosnowiec, Poland, phone +483236894 66, email: gjj37@wp.pl

${ }^{4}$ Department of Analytical Chemistry, Faculty of Chemistry, Gdansk University of Technology, ul. G. Narutowicza 11/12, 80-233 Gdańsk, Poland, phone +48 58347 21 10, email: zanpolko@pg.gda.pl

* Corresponding author: zanpolko@pg.gda.pl
} 
elements of the environment. Specific properties of surface-active agents lead to their increased mobility and free movement between different elements of the environment $[2,3]$.

Most of the global production (about 65\%) of surface active agents are anionic surfactants [4]. Polar parts of anionic molecules of surfactants contain carboxylic, sulphonic, sulphonate and phosphoric functional groups. Counterions in their molecules include such ions as sodium, potassium, lithium, calcium or protonated amines. Linear alkylbenzene sulphonates (LAS) are chemical compounds used at the largest scale of all anionic surfactants. Their molecules contain a sulphonated aromatic ring attached to an alkyl chain containing from 10 to 16 hydrocarbon groups. Other two groups of surfactants that are the most often used in different areas after LAS compounds include alkyl ethoxy sulphates (AES) and alkyl sulphates (AS) that are produced in the process of sulphonation of ethoxylated alcohols (EA). Molecules of AES compounds contain an alkyl chain built from 11 to up to 17 hydrocarbon groups and up to 8 ethoxylated groups attached to a sulphate functional group. Alkyl sulphate molecules only have an alkyl chain consisting of 12-18 hydrocarbon groups attached to a functional group [4, 5].

The presence of anionic surfactants has been confirmed in samples of atmospheric precipitation and deposits, surface water, bottom sediments, soil and living organisms taken in populated and industrial areas [6-11]. They accumulate in organisms living in aqueous environment and can affect their cell membranes, proteins and enzymes. This phenomenon can lead to impairment of vital functions, cell decay or even death of living organisms. It has also been established that the presence of anionic surfactants leads to lowering surface tension in cells and thus increased susceptibility to absorbing other toxic pollutants by living organisms $[12,13]$.

Moreover, surface-active substances that are present in aqueous environment are able to form a film on the surface of water, lowering its surface tension. This phenomenon potentially hampers water evaporation and gas transport processes in aqueous ecosystems. The presence of surfactants may lead to increased solubility of other pollutants otherwise poorly soluble in water, what in turn leads to increased mobility of various toxic compounds in aqueous ecosystems [14].

The above mentioned possible impacts of surfactants on the environment prove that it is extremely important to obtain reliable information about the content of anionic surfactants (and products of their breakdown and metabolism) in the water of rivers flowing through industrial areas $[2,3,15,16]$.

In the course of the carried out research environmental samples taken in the Klodnica catchment were used. This catchment is located in a highly urbanised and industrialised area where various pollutants are constantly discharged to aqueous ecosystems as a result of human activity. In the Klodnica catchment surface and underground mining of mineral resources (e.g. hard coal) is carried out, what leads to irreversible changes in the hydrographic network of this aqueous ecosystem (land subsidence processes, formation of reservoirs filling the created basins). Moreover, it has been established on the basis of long-term research that the Klodnica is highly polluted throughout its nearly whole length due to the emission of various chemical compounds with treated effluents or their discharge without previous treatment. The above aspects confirm the possibility of pollution of the Klodnica's ecosystem with surfactants and comprehensive research in this area is justified $[17,18]$. 


\section{Experimental procedures}

\section{Sampling site and sampling method}

The carried out research comprised surface water and bottom sediment samples taken in the Klodnica catchment in the period from 2010 to 2013 (liquid samples - four times each year, solid samples - twice in 2012 and 2013). Figure 1 and Table 1 present the location of sampling sites where liquid and solid environmental samples were taken.

a)

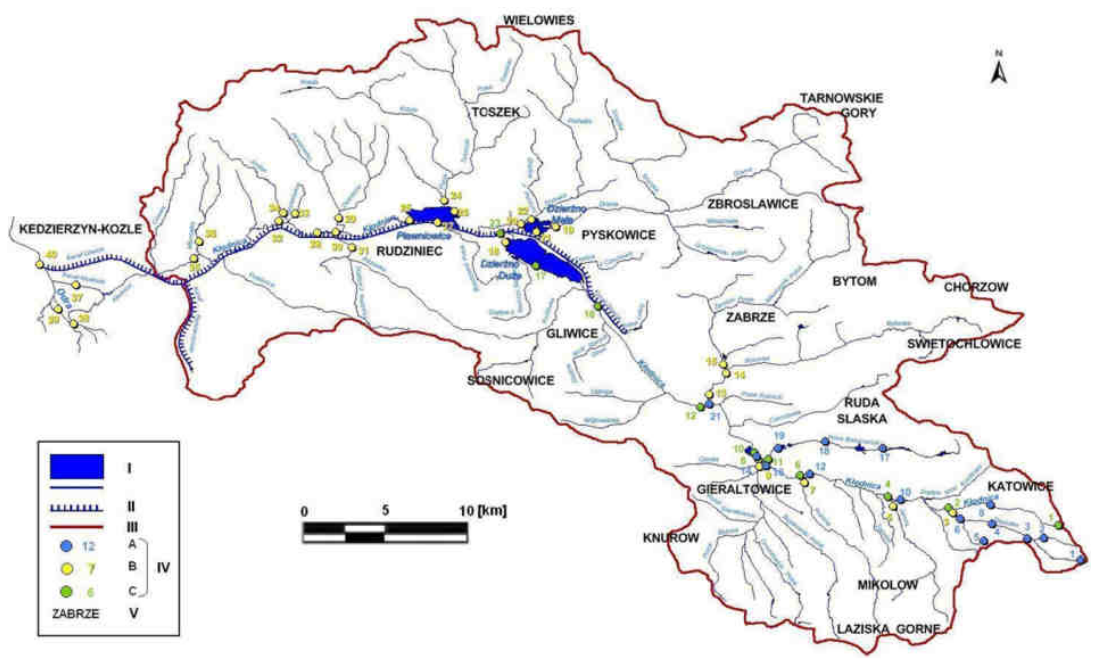

b)

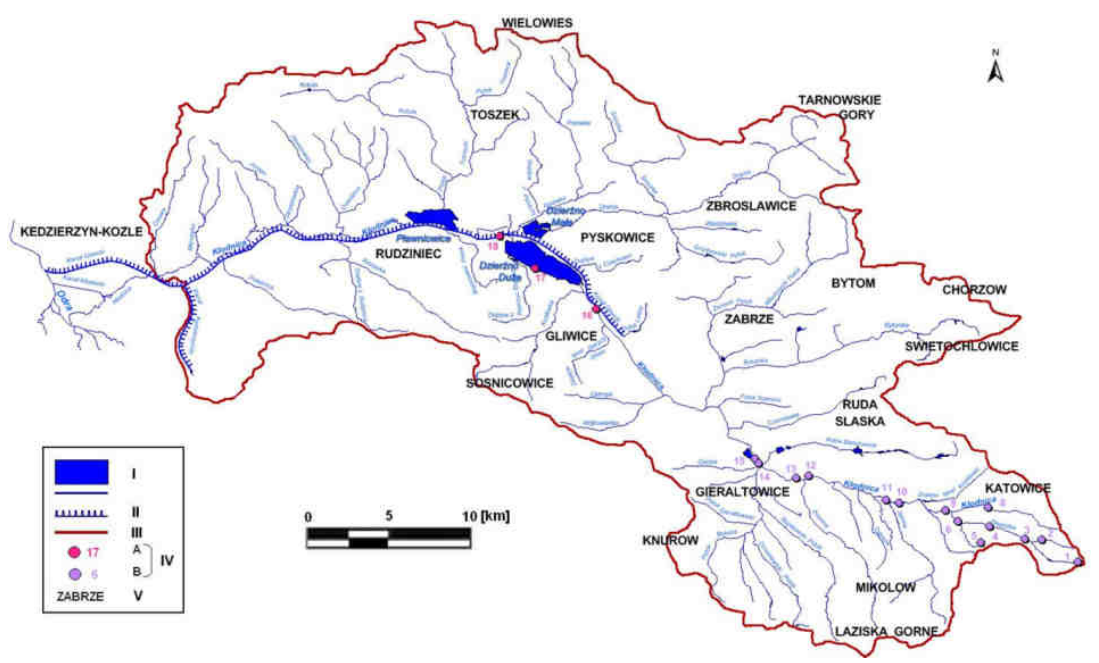

Fig. 1. Surface water (a) and bottom sediment (b) sampling sites. Key: I - watercourses and reservoirs; II - canals; III - borders of the Klodnica catchment; V - cities and a) IV - sampling sites: A - liquid samples taken in 2010-2012, B - liquid samples in 2013, C - samples taken in each campaign; b) IV - sampling sites: A - deposit samples taken in 2012, B - deposit samples taken in 2012 and 2013 
Information on the samples

\begin{tabular}{|c|c|c|c|c|c|c|}
\hline \multirow{3}{*}{$\begin{array}{c}\text { Determi- } \\
\text { nation of } \\
\text { the samples } \\
\text { used in } \\
\text { a study }\end{array}$} & \multirow{3}{*}{$\begin{array}{l}\text { Location of environmental } \\
\text { samples }\end{array}$} & \multirow{3}{*}{ GPS coordinates } & \multicolumn{2}{|c|}{\begin{tabular}{|c|} 
a) surface water \\
samples taken \\
during the \\
$2010-2012$ and 2013 \\
\end{tabular}} & \multicolumn{2}{|c|}{$\begin{array}{c}\text { b) samples of } \\
\text { bottom sediments } \\
\text { collected in } 2012 \\
\text { and } 2013 \text { years } \\
\end{array}$} \\
\hline & & & \multicolumn{4}{|c|}{\begin{tabular}{|c|}
$\begin{array}{c}\text { Number of samples taken and number of } \\
\text { points }\end{array}$ \\
\end{tabular}} \\
\hline & & & \begin{tabular}{|c|} 
Samples \\
$\mathbf{2 0 1 0 - 2 0 1 2}$ \\
$(n=23)$
\end{tabular} & \begin{tabular}{|c|} 
Samples \\
2013 \\
$(n=40)$ \\
\end{tabular} & $\begin{array}{c}\text { Samples } \\
2012 \\
(n=10) \\
\end{array}$ & $\begin{array}{c}\text { Samples } \\
2013 \\
(n=15) \\
\end{array}$ \\
\hline W1 & Source of Klodnica & $\begin{array}{l}50^{\circ} 13^{\prime} 10.48^{\prime \prime} \mathrm{N} \\
19^{\circ} 00^{\prime} 37.36^{\prime \prime} \mathrm{E}\end{array}$ & 7 & 1 & - & - \\
\hline $\begin{array}{l}\mathrm{W} / 2 \\
\mathrm{O} / 2 \\
\end{array}$ & Klodnica - Kokociniec & $\begin{array}{l}50^{\circ} 13^{\prime} 96.2^{\prime \prime} \mathrm{N} \\
18^{\circ} 57^{\prime} 22.3{ }^{\prime \prime} \mathrm{E} \\
\end{array}$ & 8 & - & 8 & 8 \\
\hline $\begin{array}{l}\mathrm{W} / 3 \\
\mathrm{O} / 3 \\
\end{array}$ & Source of Slepiotka & $\begin{array}{l}50^{\circ} 12^{\prime} 1.60^{\prime \prime} \mathrm{N} \\
19^{\circ} 02^{\prime} 1.211^{\prime \prime} \mathrm{E} \\
\end{array}$ & 1 & - & 1 & 1 \\
\hline $\begin{array}{l}\mathrm{W} / 4 \\
\mathrm{O} / 4\end{array}$ & $\begin{array}{l}\text { The source the } 1^{\text {-st }} \text { inflow of } \\
\text { Slepiotka }\end{array}$ & $\begin{array}{l}50^{\circ} 12^{\prime} 71.6^{\prime \prime} \mathrm{N} \\
18^{\circ} 59^{\prime} 62.2^{\prime \prime} \mathrm{E}\end{array}$ & 2 & - & 2 & 2 \\
\hline $\begin{array}{l}\mathrm{W} / 5 \\
\mathrm{O} / 5\end{array}$ & $\begin{array}{l}\text { Slepiotka - downstream of the } \\
\text { confluence of } 1^{\text {-st }} \text { inflow }\end{array}$ & $\begin{array}{l}50^{\circ} 12^{\prime} 71.5 ” \mathrm{~N} \\
18^{\circ} 59^{\prime} 61.1^{\prime \prime} \mathrm{E}\end{array}$ & 3 & - & 3 & 3 \\
\hline $\begin{array}{l}\mathrm{W} / 6 \\
\mathrm{O} / 6\end{array}$ & Slepiotka - settlement of Zadole & $\begin{array}{l}50^{\circ} 13^{\prime} 19.9{ }^{\prime \prime} \mathrm{N} \\
18^{\circ} 37^{\prime} 65.5^{\prime \prime} \mathrm{E} \\
\end{array}$ & 4 & - & 4 & 4 \\
\hline $\begin{array}{l}\mathrm{W} / 8 \\
\mathrm{O} / 8 \\
\end{array}$ & $\begin{array}{l}\text { Slepiotka - downstream of the } \\
\text { confluence of } 2^{\text {-nd }} \text { inflow }\end{array}$ & $\begin{array}{c}50^{\circ} 13^{\prime} 43.00^{\prime \prime} \mathrm{N} \\
18^{\circ} 55^{\prime} 82.4^{\prime \prime} \mathrm{E} \\
\end{array}$ & 6 & - & 6 & 6 \\
\hline $\begin{array}{l}\mathrm{W} / 9 \\
\mathrm{O} / 9\end{array}$ & $\begin{array}{l}\text { Downstream of the confluence of } \\
\text { the Slepiotka to the Klodnica }\end{array}$ & $\begin{array}{l}50^{\circ} 13^{\prime} 48.93 ” \mathrm{~N} \\
18^{\circ} 54^{\prime} 59.57^{\prime \prime} \mathrm{E}\end{array}$ & 9 & 2 & 9 & 9 \\
\hline W10 & $\begin{array}{l}\text { Estuary of the Slepiotka to the } \\
\text { Klodnica }\end{array}$ & $\begin{array}{l}50^{\circ} 13 ’ 41.73 ” \mathrm{~N} \\
18^{\circ} 55^{\prime} 27.81 \text { 'E }\end{array}$ & - & 3 & - & - \\
\hline $\begin{array}{l}\mathrm{W} / 11 \\
\mathrm{O} / 11 \\
\end{array}$ & $\begin{array}{l}\text { Klodnica - above the confluence of } \\
\text { Jamna }\end{array}$ & $\begin{array}{l}50^{\circ} 14 ' 01.9{ }^{\prime} \mathrm{N} \\
18^{\circ} 52^{\prime} 17.66^{\prime \prime} \mathrm{E} \\
\end{array}$ & 10 & - & 10 & 10 \\
\hline $\begin{array}{l}\mathrm{W} / 16 \\
\mathrm{O} / 16 \\
\end{array}$ & $\begin{array}{l}\text { Downstream of the confluence of } \\
\text { the Promna to the Klodnica }\end{array}$ & $\begin{array}{l}50^{\circ} 14^{\prime} 47,47^{\prime \prime} \mathrm{N} \\
18^{\circ} 47^{\prime} 18,99^{\prime \prime} \mathrm{E} \\
\end{array}$ & 13 & 6 & 13 & 13 \\
\hline $\begin{array}{l}\mathrm{W} / 17 \\
\mathrm{O} / 17\end{array}$ & $\begin{array}{l}\text { Above the confluence of the Potok } \\
\text { Bujakowski to the Klodnica }\end{array}$ & $\begin{array}{l}50^{\circ} 15^{\prime} 18,28^{\prime \prime} \mathrm{N} \\
18^{\circ} 45^{\prime} 30,34^{\prime \prime} \mathrm{E}\end{array}$ & 14 & - & 14 & 14 \\
\hline $\begin{array}{l}\mathrm{W} / 19 \\
\mathrm{O} / 19\end{array}$ & $\begin{array}{c}\text { Downstream of the confluence of } \\
\text { the Potok Bujakowski to the } \\
\text { Klodnica }\end{array}$ & $\begin{array}{l}50^{\circ} 15^{\prime} 18,28^{\prime}, \mathrm{N} \\
18^{\circ} 45^{\prime} 30,34^{\prime}, \mathrm{E}\end{array}$ & 15 & 8 & 15 & 15 \\
\hline W22 & $\begin{array}{c}\text { Potok Bielszowicki - for KWK } \\
\text { Bielszowice }\end{array}$ & $\begin{array}{l}50^{\circ} 16,774{ }^{\prime} \mathrm{N} \\
18^{\circ} 50,325^{\prime} \mathrm{E}\end{array}$ & 18 & - & - & - \\
\hline W23 & $\begin{array}{l}\text { Estuary of the Potok Bielszowicki } \\
\text { (Kochlowka) to the Klodnica }\end{array}$ & $\begin{array}{l}50^{\circ} 15^{\prime} 20,08^{\prime \prime} \mathrm{N} \\
18^{\circ} 45^{\prime} 47,81^{\prime}, \mathrm{E} \\
\end{array}$ & 19 & 11 & - & - \\
\hline W24 & $\begin{array}{c}\text { Downstream of the confluence of } \\
\text { the Potok Bielszowicki to the } \\
\text { Klodnica }\end{array}$ & $\begin{array}{l}50^{\circ} 15^{\prime} 30,02{ }^{\prime}, \mathrm{N} \\
18^{\circ} 45^{\prime} 16,95^{\prime} \mathrm{E}\end{array}$ & 20 & 10 & - & - \\
\hline W26 & $\begin{array}{l}\text { Downstream of the confluence of } \\
\text { the Bytomka to the Klodnica }\end{array}$ & $\begin{array}{l}50^{\circ} 17^{\prime} 09,23^{\prime \prime} \mathrm{N} \\
18^{\circ} 42^{\prime} 39,46^{\prime} \mathrm{E} \\
\end{array}$ & 22 & 12 & - & - \\
\hline W27 & $\begin{array}{c}\text { Estuary of the Bytomka to the } \\
\text { Klodnica }\end{array}$ & $\begin{array}{l}50^{\circ} 17^{\prime} 24,14^{\prime \prime} \mathrm{N} \\
18^{\circ} 42^{\prime} 44,27^{\prime} \mathrm{E}\end{array}$ & - & 13 & - & - \\
\hline W29 & $\begin{array}{c}\text { Estuary of the Potok Zernicki to the } \\
\text { Bytomka }\end{array}$ & $\begin{array}{l}50^{\circ} 19^{\prime} 21,86^{\prime \prime} \mathrm{N} \\
18^{\circ} 42^{\prime} 254,62^{\prime \prime} \mathrm{E}\end{array}$ & - & 15 & - & - \\
\hline $\begin{array}{l}\mathrm{W} / 30 \\
\mathrm{O} / 30 \\
\end{array}$ & $\begin{array}{l}\text { Estuary of the Klodnica to the } \\
\text { Dzierzno Duze }\end{array}$ & $\begin{array}{l}50^{\circ} 20^{\prime} 24,933^{\prime \prime} \mathrm{N} \\
18^{\circ} 37^{\prime} 12,644^{\prime} \mathrm{E} \\
\end{array}$ & 23 & 16 & - & 16 \\
\hline W32 & $\begin{array}{l}\text { Reservoir of Dzierzno Duze (the } \\
\text { western part of reservoir) }\end{array}$ & $\begin{array}{l}50^{\circ} 22^{\prime} 21,28^{\prime \prime} \mathrm{N} \\
18^{\circ} 32^{\prime} 16,06^{\prime} \mathrm{E} \\
\end{array}$ & - & 18 & - & - \\
\hline W33 & $\begin{array}{l}\text { Estuary of the Drama to the } \\
\text { Dzierzno Male }\end{array}$ & $\begin{array}{l}50^{\circ} 23^{\prime} 01,39^{\prime \prime} \mathrm{N} \\
18^{\circ} 34^{\prime} 36,82^{\prime \prime} \mathrm{E} \\
\end{array}$ & - & 19 & - & - \\
\hline
\end{tabular}




\begin{tabular}{|c|c|c|c|c|c|c|}
\hline $\begin{array}{l}\mathrm{W} / 36 \\
\mathrm{O} / 36\end{array}$ & $\begin{array}{c}\text { Dzierzno Male (the western part of } \\
\text { reservoir) }\end{array}$ & $\begin{array}{l}50^{\circ} 23^{\prime} 19,46^{\prime \prime} \mathrm{N} \\
18^{\circ} 33^{\prime} 53,00^{\prime \prime} \mathrm{E}\end{array}$ & - & 22 & - & 17 \\
\hline W37 & $\begin{array}{l}\text { The Gliwice Channel at the estuary } \\
\text { of Drama and Klodnica }\end{array}$ & $\begin{array}{l}50^{\circ} 22^{\prime} 45,47^{\prime \prime} \mathrm{N} \\
18^{\circ} 31^{\prime} 37,99^{\prime \prime} \mathrm{E}\end{array}$ & 25 & 23 & - & - \\
\hline $\begin{array}{l}\mathrm{W} / 40 \\
\mathrm{O} / 40\end{array}$ & $\begin{array}{l}\text { The Lake Plawniowice (the northern } \\
\text { part of lake) }\end{array}$ & $\begin{array}{l}50^{\circ} 23^{\prime} 34,077^{\prime \prime} \mathrm{N} \\
18^{\circ} 29^{\prime} 33,96^{\prime} \mathrm{E}\end{array}$ & - & 26 & - & 18 \\
\hline W41 & $\begin{array}{l}\text { The Lake Plawniowice (the } \\
\text { southern part of lake) }\end{array}$ & $\begin{array}{l}50^{\circ} 23^{\prime} 15,86^{\prime \prime} \mathrm{N} \\
18^{\circ} 28^{\prime} 25,25{ }^{\prime} \mathrm{E}\end{array}$ & - & 27 & - & - \\
\hline W42 & $\begin{array}{c}\text { Downstream of the confluence the } \\
\text { Jaryszowka }\end{array}$ & $\begin{array}{l}50^{\circ} 22^{\prime} 50,95^{\prime \prime} \mathrm{N} \\
18^{\circ} 22^{\prime} 59,17^{\prime}, \mathrm{E}\end{array}$ & - & 28 & - & - \\
\hline W44 & $\begin{array}{l}\text { Downstream of the confluence of } \\
\text { the Klodnica to Klodnica }\end{array}$ & $\begin{array}{l}50^{\circ} 22^{\prime} 41,233^{\prime \prime} \mathrm{N} \\
18^{\circ} 23,11,96^{\prime \prime} \mathrm{E}\end{array}$ & - & 30 & - & - \\
\hline W46 & $\begin{array}{l}\text { Downstream of the confluence of } \\
\text { the Jaroszowiec to the Klodnica }\end{array}$ & $\begin{array}{l}50^{\circ} 23^{\prime} 11,75^{\prime \prime} \mathrm{N} \\
18^{\circ} 20^{\prime} 34,22^{\prime} \mathrm{E}\end{array}$ & - & 32 & - & - \\
\hline W48 & $\begin{array}{l}\text { Estuary of the Jordan to the } \\
\text { Klodnica }\end{array}$ & $\begin{array}{l}50^{\circ} 23^{\prime} 16,94^{\prime \prime} \mathrm{N} \\
18^{\circ} 20^{\prime} 50,74^{\prime}, \mathrm{E}\end{array}$ & - & 34 & - & - \\
\hline W51 & $\begin{array}{l}\text { The Klodnica Channel before the } \\
\text { confluence to the Odra }\end{array}$ & $\begin{array}{l}50^{\circ} 20^{\prime} 59,85^{\prime \prime} \mathrm{N} \\
18^{\circ} 10^{\prime} 04,12^{\prime}, \mathrm{E}\end{array}$ & - & 37 & - & - \\
\hline W54 & $\begin{array}{l}\text { The Odra after the estuary to the } \\
\text { Klodnica Channel }\end{array}$ & $\begin{array}{l}50^{\circ} 21^{\prime} 41,25^{\prime \prime} \mathrm{N} \\
18^{\circ} 08^{\prime} 09,92^{\prime}, \mathrm{E}\end{array}$ & - & 40 & - & - \\
\hline
\end{tabular}

After collection, liquid samples were transported to the laboratory and stored in reduced temperature until the process of isolation of analytes was carried out with the use of certain analytical techniques (in order to prepare solvent extracts). After collection, samples of bottom sediments were also transported to the laboratory where they were freeze-dried and then stored in a reduced temperature, just like in the case of liquid samples.

\section{Analytical laboratory methods}

Table 2 presents basic information concerning selected analytes from the surfactants group, like molar masses, chemical structure and toxicity details of the determined compounds.

Table 2

Basic information concerning properties of selected analytes from the surfactants group

\begin{tabular}{|c|c|c|c|c|}
\hline $\begin{array}{c}\text { Name/ } \\
\text { chemical formula }\end{array}$ & $\begin{array}{c}\mathbf{M} \\
{[\mathrm{g} / \mathrm{mol}]}\end{array}$ & $\begin{array}{c}\text { Harmful effects } \\
\text { on humans }\end{array}$ & Toxicity towards animals & References \\
\hline $\begin{array}{c}\text { Sodium linear } \\
\text { alkylbenzene } \\
\text { sulphonates (LAS) } \\
\mathrm{C}_{16-19} \mathrm{H}_{25-33} \mathrm{NaO}_{3} \mathrm{~S}\end{array}$ & $320-348$ & $\begin{array}{cl}\text { Causes burns of: } \\
\bullet & \text { eyes } \\
\bullet & \text { skin }\end{array}$ & $\begin{array}{c}\text { Daphnia magna } \mathrm{LC}_{50}=13.9 \mathrm{mg} / \mathrm{dm}^{3}(48 \mathrm{~h}) \\
\text { Dunaliella salina } \mathrm{EC}_{50}=3.5 \mathrm{mg} / \mathrm{dm}^{3}(24 \mathrm{~h}) \\
\text { Daphnia magna } \mathrm{LC}_{50}=8.1 \mathrm{mg} / \mathrm{dm}^{3}(48 \mathrm{~h}) \\
\text { Daphnia magna } \mathrm{LC}_{50}=1.22 \mathrm{mg} / \mathrm{dm}^{3}(48 \mathrm{~h}) \\
\text { Mouse: } \mathrm{LD}_{50}=1575 \mathrm{mg} / \mathrm{kg} \text { (orally) } \\
\text { Rat: } \mathrm{LD}_{50}=404 \mathrm{mg} / \mathrm{kg} \text { (orally) }\end{array}$ & [19-21] \\
\hline
\end{tabular}

In most cases there are no commercially available suitable standard solutions of the surfactants that are the subject of research, so products with highest available purity were used to prepare basic standard solutions of certain analyte ions with the concentration of $1000 \mu \mathrm{g} / \mathrm{cm}^{3}$.

Analytes were dissolved in a small volume of mixture of methanol and deionised water $(1: 1, \mathrm{v} / \mathrm{v})$ and filled up with enough deionised water to obtain the required volume. Moreover, to limit the process of degradation of analytes, 3 drops of $36 \%$ hydrochloric acid were added to the solutions of standard substances. 
Then the stock solutions were used to prepare standard mixtures containing certain concentrations of anionic surfactants that were later used at certain stages of analytical procedures. Table 3 contains a breakdown of operating parameters of a chromatographic system during analyses. On the basis of the available literature data, types of fillers of analytical columns and mobile phases used at the stage of separating analytes from the surfactants group were chosen. However, the following parameters were chosen empirically: volume of the dispensed sample, mobile phase flow rate, column temperature or wavelength at the detection stage.

Table 3

Operating conditions of a chromatographic system during identification and quantitative determination of analytes from the anionic surfactants group in environmental samples

\begin{tabular}{|c|c|}
\hline Device type & Ion chromatography system ICS-3000 with autosampler \\
\hline Analyte type & $\mathrm{C}_{10}-\mathrm{C}_{13}$ LAS \\
\hline Volume of dispensed sample $\left[\mathbf{c m}^{3}\right]$ & 0.005 \\
\hline Eluent composition & A: $100 \%$ ACN \\
\hline Mobile phase flow rate $\left[\mathbf{c m}^{3} / \mathbf{m i n}\right]$ & B: ACN $+100 \mathrm{mM} \mathrm{AMAC}(\mathrm{pH}=5)(70: 30, \mathrm{v}: \mathrm{v})$ \\
\hline Analytical column (Column diameter/length & 0.3 \\
\hline$[\mathbf{m m}]$ ) & Acclaim ${ }^{\circledR}$ Surfactant Plus $(2.1 / 150)$ \\
\hline Column temperature $\left[{ }^{\circ} \mathbf{C}\right]$ & 30 \\
\hline Detector type & Spectrophotometer detector operating in the UV light range \\
\hline Wavelength at the detection stage [nm] & 225 \\
\hline Time of analysis [min] & 20 \\
\hline
\end{tabular}

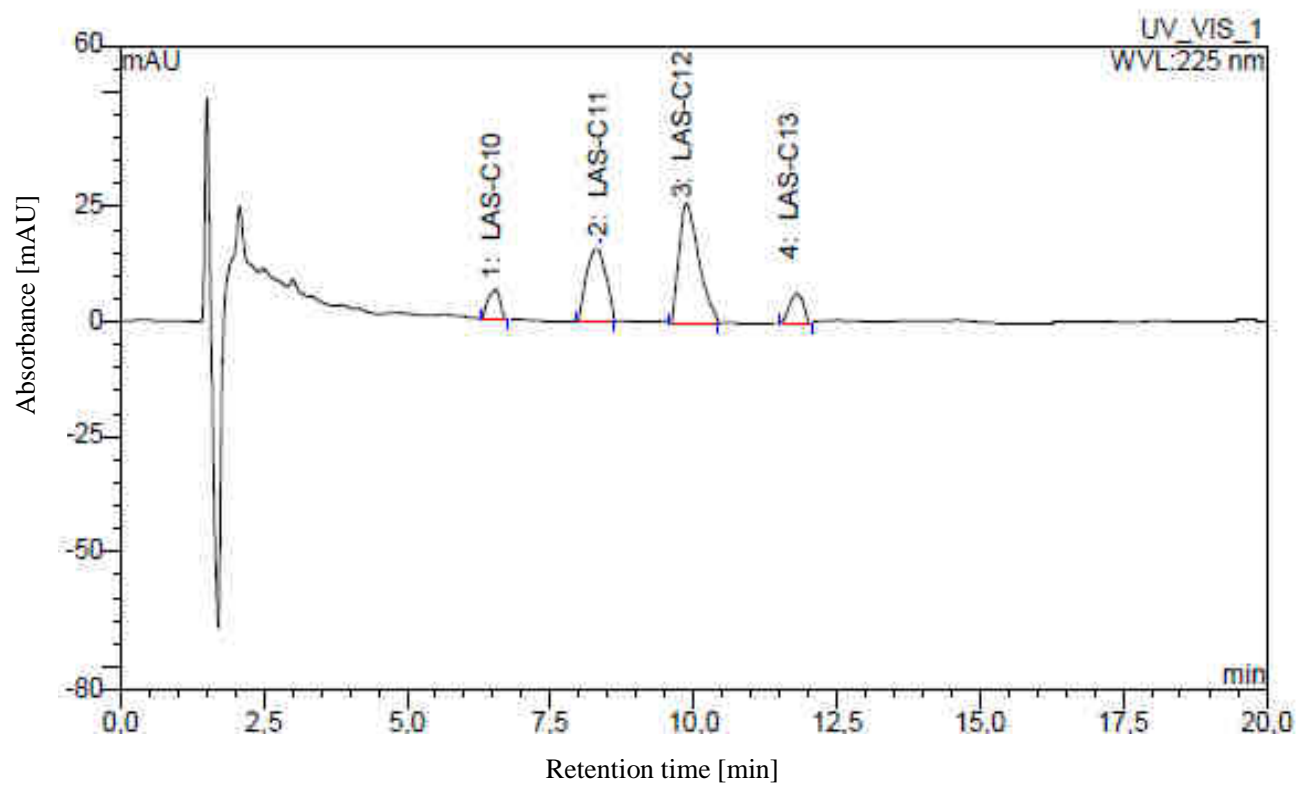

Fig. 2. Chromatogram obtained as a result of chromatographic analysis of a sample of a mixture of standard substances with the concentration of $1-3.3 \mathrm{mg} / \mathrm{dm}^{3}$ with the use of HPIC-UV technique (in optimised conditions) 
As a result of analysis chromatograms were obtained presenting the dependence of absorption of radiation of a certain wavelength by molecules of analytes on the time of analysis. A sample chromatogram of a standard solution obtained as a result of chromatography analysis with the use of HPIC-UV system (according to the conditions presented in Table 3) is presented in Figure 2.

In order to make calibration curves a series of water solutions of standard substances was prepared, that contained particular anionic surfactants with concentrations ranging from 5.0 to $3500 \mu \mathrm{g} / \mathrm{dm}^{3}$. These solutions were subject to chromatographic analysis in three independent tests. Then calibration curves presenting the dependence of peak area of a certain analyte on its concentration were made. Parameters of calibration curves created with the use of the HPIC-UV system and the calculated values of LOD and LOQ parameters for selected anionic surfactants are presented in Table 4.

Table 4

Parameters of calibration curves for selected anionic surfactants

\begin{tabular}{|c|c|c|c|c|c|c|}
\hline Analyte & \begin{tabular}{|c|} 
Analyte \\
retention time \\
[min]
\end{tabular} & $\begin{array}{c}\text { Concentration } \\
\text { range } \\
{\left[\mu \mathrm{g} / \mathrm{dm}^{3}\right]}\end{array}$ & $\begin{array}{c}\text { Calibration curve } \\
\text { equation }\end{array}$ & $\begin{array}{l}\text { Regression } \\
\text { coefficient } r\end{array}$ & $\begin{array}{c}\text { LOD } \\
{\left[\mu \mathrm{g} / \mathbf{d m}^{3}\right]}\end{array}$ & $\begin{array}{c}\mathrm{LOQ} \\
{\left[\mu \mathrm{g} / \mathrm{dm}^{3}\right]}\end{array}$ \\
\hline \multirow{2}{*}{$\mathrm{C}_{10} \mathrm{LAS}$} & \multirow{2}{*}{6.7} & LOQ-500 & $y=0.616 x+0.066$ & 0.9985 & \multirow{2}{*}{4.5} & \multirow{2}{*}{13.5} \\
\hline & & $500-2500$ & $y=1.214 x+0.121$ & 0.9993 & & \\
\hline \multirow{2}{*}{$\mathrm{C}_{11} \mathrm{LAS}$} & \multirow{2}{*}{8.4} & LOQ-500 & $y=0.331 x+0.137$ & 0.9997 & \multirow{2}{*}{10.1} & \multirow{2}{*}{30.3} \\
\hline & & $500-3500$ & $y=0.894 x+0.054$ & 0.9998 & & \\
\hline \multirow{2}{*}{$\mathrm{C}_{12} \mathrm{LAS}$} & \multirow{2}{*}{9.9} & LOQ-500 & $y=0.154 x+0.012$ & 0.9989 & \multirow{2}{*}{8.4} & \multirow{2}{*}{25.2} \\
\hline & & $500-3500$ & $y=0.851 x+0.109$ & 0.9991 & & \\
\hline \multirow{2}{*}{$\mathrm{C}_{13} \mathrm{LAS}$} & \multirow{2}{*}{12.4} & LOQ-500 & $y=0.267 x+0.165$ & 0.9979 & \multirow{2}{*}{11.3} & \multirow{2}{*}{33.9} \\
\hline & & $500-2500$ & $y=0.813 x+0.105$ & 0.9986 & & \\
\hline
\end{tabular}

The calculated values of selected validation parameters of the developed methodologies of determination of selected anionic surfactants in liquid and solid environmental samples are presented in Table 5.

Table 5

Values of selected validation parameters for proposed analytical methodologies determined with the use of ionic chromatography

\begin{tabular}{|c|c|c|c|c|c|c|}
\hline \multirow[t]{2}{*}{ Analytes } & \multirow{2}{*}{$\begin{array}{c}\text { Range of } \\
\text { concentrations } \\
{\left[\mu \mathrm{g} / \mathrm{dm}^{3}\right]}\end{array}$} & \multirow{2}{*}{$\begin{array}{c}\text { Calibration curve } \\
\text { equation }\end{array}$} & \multirow{2}{*}{$\begin{array}{l}\text { Regression } \\
\text { coefficient } r\end{array}$} & \multirow{2}{*}{\begin{tabular}{|c|} 
LOD \\
{$\left[\mu \mathrm{g} / \mathrm{dm}^{3}\right]$ or } \\
{$[\mu \mathrm{g} / \mathrm{kg}]$}
\end{tabular}} & \multirow{2}{*}{$\begin{array}{c}\text { LOQ } \\
{\left[\mu \mathrm{g} / \mathrm{dm}^{3}\right] \text { or }} \\
{[\mu \mathrm{g} / \mathrm{kg}]}\end{array}$} & $\begin{array}{l}\text { Analyte recovery } \\
(\mathrm{CV}[\%])(n=3)\end{array}$ \\
\hline & & & & & & Repeatability \\
\hline \multirow{2}{*}{$\mathrm{C}_{10}$-LAS } & \multirow{2}{*}{ LOQ-2500 } & $y=0.684 x+0.018$ & 0.9986 & 8.3 & 25 & $89.4(3.8)$ \\
\hline & & $y=0.906 x+0.087 *$ & $0.9985 *$ & $12 *$ & $36^{*}$ & $88.9(3.6)^{*}$ \\
\hline \multirow{2}{*}{$\mathrm{C}_{11}$-LAS } & \multirow{2}{*}{ LOQ-3500 } & $y=0.402 x+0.099$ & 0.9994 & 11 & 33 & $101.2(2.5)$ \\
\hline & & $y=0.427 x+0.133^{*}$ & $0.9991^{*}$ & $18^{*}$ & $53^{*}$ & $96.4(3.0)^{*}$ \\
\hline \multirow{2}{*}{$\mathrm{C}_{12}$-LAS } & \multirow{2}{*}{ LOQ-3500 } & $y=0.193 x+0.0588$ & 0.9995 & 9.8 & 29 & $93.1(1.4)$ \\
\hline & & $y=0.212 x+0.013^{*}$ & $0.9993 *$ & $14 *$ & $42 *$ & $96.4(2.8)^{*}$ \\
\hline \multirow{2}{*}{$\mathrm{C}_{13}$-LAS } & \multirow{2}{*}{ LOQ-2500 } & $y=0.298 x+0.112$ & 0.9997 & 12 & 36 & $97.2(4.1)$ \\
\hline & & $y=0.307 x+0.101^{*}$ & $0.9992^{*}$ & $19 *$ & $54 *$ & $96.9(7.2)^{*}$ \\
\hline
\end{tabular}

* selected parameters concern solid samples

\section{Results}

Table 6 presents the results obtained at the time of determination of content of analytes from the group of linear alkylbenzene sulphonates in the analysed environmental samples. 
Table 6

Content levels of surfactants from the LAS group determined in liquid and solid environmental samples with the use of the developed analytical procedures

\begin{tabular}{|c|c|c|c|c|}
\hline $\begin{array}{c}\text { Sample } \\
\text { determination }\end{array}$ & $\mathrm{C}_{10}$-LAS & $\mathrm{C}_{11}$-LAS & $\mathrm{C}_{12}$-LAS & $\mathrm{C}_{13}$-LAS \\
\hline \multicolumn{5}{|c|}{ Surface water $\left[\mathrm{mg} / \mathrm{dm}^{3}\right]$} \\
\hline$c_{\min } \pm U(k=2)$ & \multicolumn{4}{|c|}{$<\mathrm{LOQ}$} \\
\hline$c_{\max } \pm U(k=2)$ & $0.240 \pm 0.018$ & $0.2105 \pm 0.0023$ & $0.1983 \pm 0.0046$ & $0.0546 \pm 0.0011$ \\
\hline $\bar{C}$ & 0.075 & 0.057 & 0.044 & 0.019 \\
\hline$S D$ & 0.052 & 0.044 & 0.040 & 0.014 \\
\hline \multicolumn{5}{|c|}{ Bottom deposit [mg/kg of sample] } \\
\hline$c_{\min } \pm U(k=2)$ & \multicolumn{4}{|c|}{$<\mathrm{LOQ}$} \\
\hline$c_{\max } \pm U(k=2)$ & $0.0784 \pm 0.0012$ & $0.137 \pm 0.017$ & $0.171 \pm 0.012$ & $0.207 \pm 0.010$ \\
\hline $\bar{C}$ & 0.037 & 0.070 & 0.096 & 0.111 \\
\hline$S D$ & 0.017 & 0.030 & 0.038 & 0.040 \\
\hline
\end{tabular}

$c_{\min } ; c_{\max }$ - the lowest and the highest determined concentration of analytes, respectively; $\bar{C}$ - arithmetic mean of the determined concentration of a given analyte in all samples taken in a given season; $S D$ - standard deviation

a)

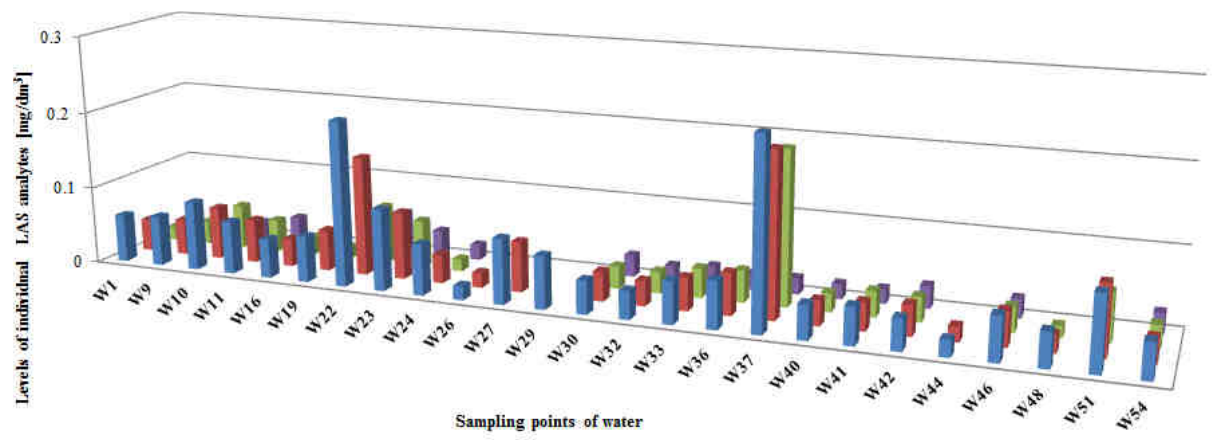

b)

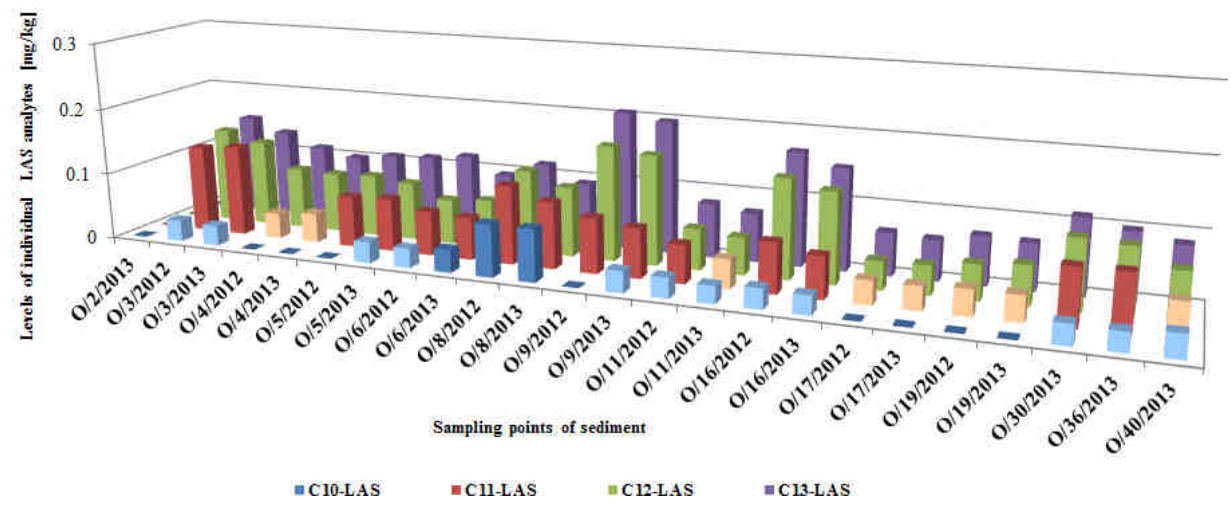

Fig. 3. Content levels of individual analytes from the LAS group in liquid (a) and solid (b) environmental samples (lighter bars in each series concern concentration values in the scope from > LOD to < LOQ) $\left(\left[\mathrm{mg} / \mathrm{dm}^{3}\right]\right.$ or $[\mathrm{mg} / \mathrm{kg}]$, respectively)

In surface water samples analytes containing shorter alkyl chains in their molecules were mainly found and determined (hydrophilicity of surfactants increases). Maximum 
determined concentrations of LAS compounds were within the range of $0.0546 \pm 0.0011$ to $0.240 \pm 0.018 \mathrm{mg} / \mathrm{dm}^{3}$, for $\mathrm{C}_{13}$-LAS and $\mathrm{C}_{10}$-LAS, respectively. In the analysed liquid samples average concentrations of selected anionic analytes were within the range of $0.019 \pm 0.014$ to $0.075 \pm 0.052 \mathrm{mg} / \mathrm{dm}^{3}$, for $C_{13}$-LAS and $C_{10}$-LAS, respectively.

In the case of test results of bottom sediment samples, the found and determined anionic surfactants were the ones with molecules built from longer alkyl chains. As in the case of liquid environmental samples, some samples of bottom sediments do not contain the analysed analytes. Maximum determined concentrations of LAS compounds are in the range between $0.0784 \pm 0.0011$ and $0.207 \pm 0.010 \mathrm{mg} / \mathrm{kg}$, for $\mathrm{C}_{10}$-LAS and $\mathrm{C}_{13}$-LAS, respectively. Average content of individual analytes from the anionic surfactants group in solid samples was determined in the range from $0.037 \pm 0.017$ up to $0.111 \pm 0.040 \mathrm{mg} / \mathrm{kg}$ of the sample, for $\mathrm{C}_{10}$-LAS and $\mathrm{C}_{13}$-LAS, respectively. The relationship between the content of LAS compounds determined in solid and liquid environmental samples and their place of collection is presented in Figure 3.

In the case of liquid samples labelled W22 and W37 we may suppose that they have been collected in areas with the greatest pollution in the researched ecosystem. On the other hand, samples of surface water labelled in the present study as W26 and W44 are the least polluted by analytes from the LAS group. Solid environmental samples labelled as O3, O9 and $\mathrm{O} 16$ contain the highest concentrations of the determined compounds from the LAS group. On the other hand, in samples labelled O2, O17 and O19 some anionic analytes were not found or they were determined at very low concentration levels.

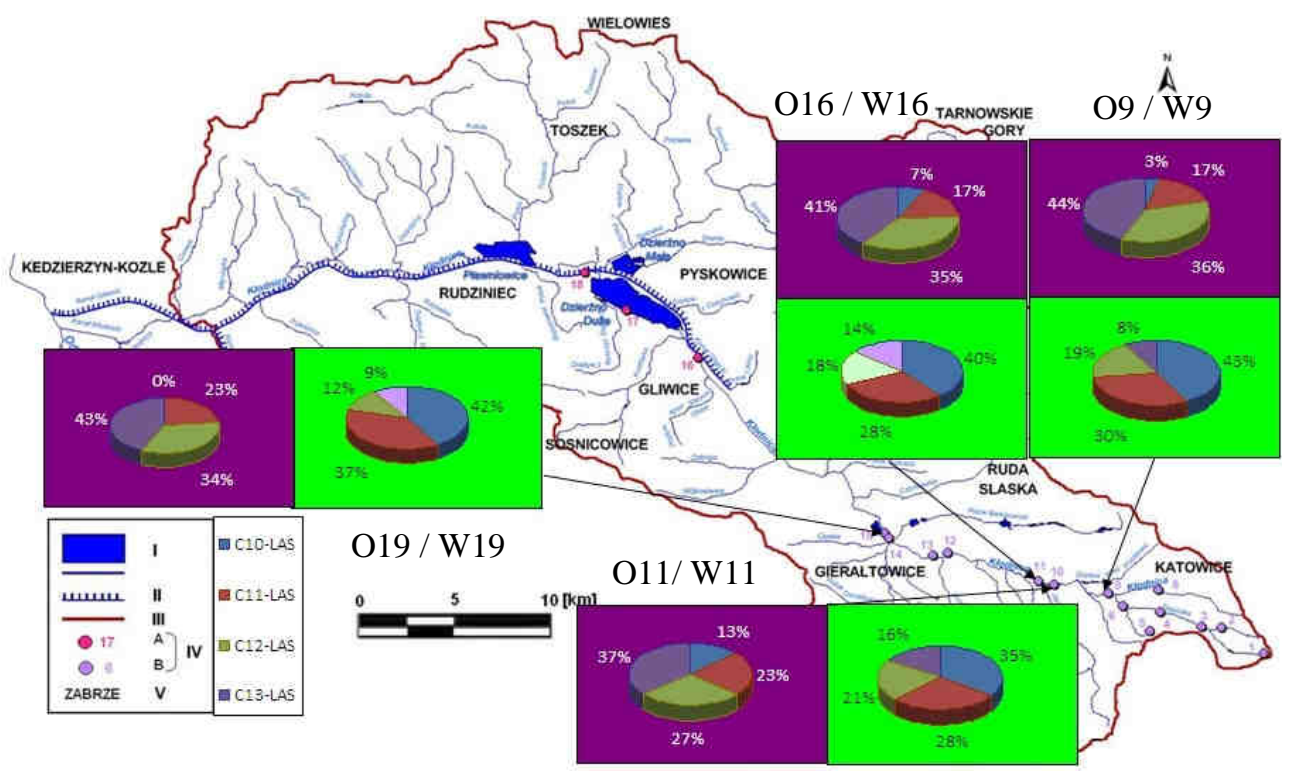

Fig. 4. Percentage relationship between the levels of concentrations of certain anionic surfactants and their summary content in liquid and solid samples collected in the same area (green colour - water samples collected in the period 2010-2012 and 2013; purple colour - samples of deposits collected in 2012 and 2013) 
Percentage relationship between concentration levels of certain anionic surfactants in liquid and solid samples collected in the same catchment area of the Klodnica river is presented in Figure 4.

Comparing the obtained percentage values of certain anionic surfactants with summary levels of their concentrations determined in environmental samples it can be stated that these relationships are similar for most batches of the tested samples. Higher concentrations of $\mathrm{C}_{10}$-LAS and $\mathrm{C}_{11}$-LAS analytes were determined in liquid samples. And higher levels of $\mathrm{C}_{12}$-LAS and $\mathrm{C}_{13}$-LAS surfactant content were determined in solid samples.

In the literature, there are described only few studies concerning compounds from the group of LAS (Table 7) [6, 8, 22].

Table 7

Determination of individual LAS in environmental samples

\begin{tabular}{|l|c|c|c|}
\hline \multicolumn{2}{|c|}{ Type of sample/origin } & $\begin{array}{c}\text { Concentration ranges of the analysed } \\
\text { compounds }\end{array}$ & Literature \\
\hline \multirow{2}{*}{ river sediments } & $0.95-11.15 \mu \mathrm{g} / \mathrm{kg}$ & {$[8]$} \\
\cline { 2 - 3 } & lake & $293-1938 \mu \mathrm{g} / \mathrm{kg}$ & {$[6]$} \\
\hline \multirow{3}{*}{ water } & river & $10.7-17.4 \mu \mathrm{g} / \mathrm{dm}^{3}$ & {$[22]$} \\
\cline { 2 - 3 } & sea & $6-204 \mu \mathrm{g} / \mathrm{dm}^{3}$ & $4-24 \mu \mathrm{g} / \mathrm{dm}^{3}$ \\
\hline
\end{tabular}

For the river polluted mainly with sewage effluent and industrial waste, the mean concentration of total homologues and isomers of LAS was significant: $0.224 \mathrm{mg} / \mathrm{dm}^{3}$ [22]. Obtained values are at the same level as the highest concentrations in the samples from the Klodnica River. Sea water samples collected from the harbour where river water taken from were analysed at different times of the year. The mean concentration of total homologues and isomers of LAS was found to be $0.058 \mathrm{mg} / \mathrm{dm}^{3}$ and it is approximately four times lower [22]. Whereas in the samples of river sediments, concentrations of a group of LAS is approximately 10 times higher [6] which is also observed for water and sediments samples collected from the Klodnica River.

\section{Conclusions}

Selected anionic surfactants were determined in samples of water from the Klodnica river (25 samples) and bottom sediments (25 samples). In most samples the presence of anionic analytes was confirmed. The determined concentration levels were in the range of up to $0.2105 \pm 0.0023 \mathrm{mg} / \mathrm{dm}^{3}$ or $0.207 \pm 0.010 \mu \mathrm{g} / \mathrm{kg}$ (surface water and bottom sediment samples, respectively). Comparing the concentrations of certain analytes found in liquid and solid environmental samples, it can be noticed that the surfactants containing a shorter alkyl chain in a molecule were present in higher concentrations in liquid samples (hydrophobicity increasing with the increasing length of the chain) and the other way round. Therefore, lower content levels of compounds from the $\mathrm{C}_{12}$-LAS and $\mathrm{C}_{13}$-LAS group in surface water samples can be the result of sorption processes on the surface of solid particles of bottom sediments. And these analytes occur in higher concentrations in solid environmental samples. Few studies described in the literature confirm these findings. 


\section{Acknowledgements}

This work has been financially supported by the Polish Ministry of Science and Higher Education (project ST - 02-0103/07 and MN - 01-0211/08/322).

The publication has been (partially) financed from the funds of the Leading National Research Centre (KNOW) received by the Centre for Polar Studies of the University of Silesia, Poland.

\section{References}

[1] Ying GG. Environ Inter. 2006;32:417-431. DOI: 10.1016/j.envint.2005.07.004.

[2] Pastewski S, Mędrzycka K. Pol J Environ Stud. 2003;12:643-646. www.pjoes.com/pdf/12.5/643-646.pdf.

[3] Olkowska E, Ruman M, Kowalska A, Polkowska Ż. Ecol Chem Eng S. 2013;20:331-342. DOI: 10.2478/eces-2013-0024.

[4] Lara-Martin PA, Gomez-Parra A, Gonzalez-Mazo E. J Chromatogr A. 2006;1114:205-210. DOI: 10.1016/j.chroma.2006.03.014.

[5] Fendinger NJ, Versteeg DJ, Wee GE, Dye RS, Rapaport RA. Environmental behaviour and fate of anionic surfactants. In: Baker LA, editor. Environmental Chemistry of Lakes and Reservoirs. ACS Advances in Chemistry Series No. 237. Washington DC, United States: American Chemical Society; 1994.

[6] Lara-Martin PA, Gomez-Parra A, Gonzalez-Mazo E. Environ Pollut. 2008;156:36-45. DOI: 10.1016/j.envpol.2008.01.005.

[7] Zhao Z, Xie Z, Möller A, Sturm R, Tang J, Zhang G, et al. Environ Pollut. 2012;170:71-77. DOI: 10.1016/j.envpol.2012.06.004.

[8] Sanderson H, Dyer SD, Price BB, Nielsen AM, van Compernolle R, Selby M, et al. Sci Total Environ. 2006;368:695-712. DOI: 10.1016/j.scitotenv.2006.04.030.

[9] Andreu V, Picó Y. Anal Chem. 2004;76:2878-2885. DOI: 10.1021/ac035483e.

[10] Clara M, Scharf S, Scheffknecht C, Gans O. Water Res. 2007;41:4339-48. DOI: 10.1016/j.watres.2007.06.027.

[11] Sanchez-Martinez ML, Aguilar-Caballos MP, Eremin SA, Gomez-Hens A. Talanta. 2007;72:243-248. DOI: 10.2174/1386207311316060010.

[12] Nomura Y, Ikebukuro K, Yokoyama K, Takeuchi T, Arikawa Y, Ohno S, et al. Biosens Bioelectron. 1998;13:1047-53. DOI: 10.1016/S0956-5663(97)00077-8.

[13] Jensen J. Sci Total Environ. 1999;226:93-111. DOI: 10.1016/S0048-9697(98)00395-7.

[14] Paria S. Adv Colloid Interface Sci. 2008;138:24-58. DOI: 10.1016/j.cis.2007.11.001.

[15] Szymański A, Wyrwas B, Jesiołowska A, Kaźmierczak S, Przybysz T, Grodecka J, et al. Pol J Environ Stud. 2001;10:371-376. http://www.pjoes.com/.

[16] Czaja S, Rahmonov O, Wach J, Gajos M. Pol J Environ Stud. 2014;23:629-637. http://www.pjoes.com/pdf/23.2/Pol.J.Environ.Stud.Vol.23.No.2.629-637.pdf.

[17] Ruman M, Olkowska E, Kozioł K, Absalon D, Matysik M, Polkowska Ż. J Environ Qual. 2014;43:753-62. DOI: $10.2134 /$ jeq2013.06.0225.

[18] Olkowska E, Kudłak B, Tsakovski S, Ruman M, Simeonov V, Polkowska Ż. Sci Total Environ. 2014;476:477-484. DOI: 10.2478/eces-2013-0033.

[19] Nagarnaik PM, Mills MA, Boulanger B. Chemosphere. 2010;78:1056-62. DOI: 10.1016/j.chemosphere.2009.11.019.

[20] Merino F, Rubio S, Pérez-Bendito D. Anal Chem. 2003;75:6799-806. DOI: 10.1021/ac030224a

[21] Nenpo K. Annual Report of Tokyo Metropolitan Research Laboratory of Public Health, 1972;24:397. www.tokyo-eiken.go.jp/assets/issue/journal/1-50/index-e.html.

[22] Akyuz M. Talanta. 2007;71:471-478. DOI: 10.1016/j.talanta.2006.06.0. 